Vol 1, No 1, Juni 2020; 47-65

ISSN : 2723-3324

Available at: e-journal.sttberitahidup.ac.id/index.php/jan/index

\title{
Preaching and Teaching Sound Doctrine Based on Christocentric Doctrine by Church Leaders for the Transformation of Church Members
}

\author{
Samuil-Ashton Satu1,2,3,4 samsatu@gmail.com
}

\begin{abstract}
Preaching and teaching sound doctrine based on Christocentric doctrine is of utmost importance to Christian belief, as it is the cornerstone of the New Testament, the Holy Trinity (the Father, the Son, and the Holy Spirit), and the Apostles. So we will not do less as Christians. The purpose of a sermon is to bring about holy transformation through the Word of God in the life of the listener. The preachers need to help the audience put the Word into their lives. With respect to this, without application, a preacher has no reason to preach. Thus he proposed five questions for the application for Christocentric doctrinal preaching, which should first be addressed to the preachers themselves. Through these questions, preachers can help to change the life of congregation by applying Christocentric doctrinal preaching. Furthermore, evidence of transformation within believers is seen in the way that the likeness and glory of Christ is increasingly reflected. The apostle Paul said, "You, however, are controlled not by the sinful nature but by the Spirit, if the Spirit of God lives in you. And if anyone does not have the Spirit of Christ, he does not belong to Christ". Believers must be led by the Spirit of God to be considered as children of God. And it is by the power of the Spirit of God that Christ is living within them. The life transformed reflects Apostle Paul's thoughts in Galatians: "I have been crucified with Christ and I no longer live, but Christ lives in me. The life I live in the body, I live by faith in the Son of God, who loved me and gave himself for me." Conversely, if the church leaders ignore Christocentric doctrinal preaching and the application of the Word of God in the church members' lives, then the transformation of the believers' lives will be thwarted. This study uses descriptive and phenomenological analysis of the data collected to find out why there is no change in some christians life-style and values. The results of this analysis will give impetus to revitalise the church to have a healthy theology for a healthy church of transformed lives in Christ Jesus.
\end{abstract}

Keywords: Preaching and Teaching, Church Leaders, Sound Doctrine, Christocentric Doctrine, Transformation

\section{Abstrak}

Berkhotbah dan mengajar doktrin yang sehat berdasarkan dokrin Kristosentrik adalah terpenting dalam kepercayaan Kristen karena itulah penegasan Perjanjian Baru, Allah Trinitas (Allah Bapa, Allah Anak dan Allah Roh Kudus) dan Rasul-Rasul. Karena itu,

\footnotetext{
${ }^{1}$ Church Elder, BEM Central Avenue Kuching, Sarawak, Malaysia

${ }^{2}$ Head of Department, Occupational Safety and Health Programme, iSystems College, JT Akademi Sdn Bhd, Kuching, Sarawak, Malaysia

${ }^{3}$ Senior Lecturer, Open University Malaysia, Kuching Learning Centre.

${ }^{4}$ Doctoral student, Sekolah Tinggi Teologi Berita Hidup, Indonesia.
} 
seorang Kristen harus juga berbuat demikian. Tujuan dari khotbah ialah transformasi hidup melalui pendengaran Firman Allah. Pengkhotbah harus membantu jemaat mengapplikasikan Firman Allah dalam hidup mereka. Tanpa aplikasi, seseorang pengkhotbah itu langsung tidak punya alasan untuk berkhotbah. Dengan itu, ia menyarankan lima hal untuk penerapan atau applikasi kepada pengkhotbah terlebih dahulu. Melalui pertanyaan ini, pengkhotbah bisa membantu kehidupan jemaat untuk diubah dengan penerapan Fiman Allah berbasiskan doktrin Kristosentrik. Selain itu, bukti transformasi dalam hidup seseorang Kristen dilihat bagaimana seseorang itu kian mencerminkan gambar dan kemuliaan Kristus. Rasul Paulus menyatakan, "Tetapi kamu tidak hidup dalam daging, melainkan dalam Roh, jika memang Roh Allah diam di dalam kamu. Tetapi jika orang tidak memiliki Roh Kristus, ia bukan milik Kristus". Untuk dianggap sebagai anak-anak Tuhan, orang percaya harus dipimpin oleh Roh Allah. Dan melalui kuasa Roh Kudus, Kristus diam di dalam mereka. Hidup transformasi mencerminkan pemikiran Rasul Paulus dalam Galatia: "Namun aku hidup, tetapi bukan lagi aku sendiri yang hidup, melainkan Kristus yang hidup di dalam aku. Dan hidupku yang kuhidup sekarang di dalam daging, adalah hidup oleh iman dalam Anak Allah yang telah mengasihi aku dan menyerahkan diri-Nya untuk aku.". Sebaliknya, jika pemimpin gereja mengabaikan khotbah doktrin Kristosentrik dan applikasi Firman Allah dalam kehidupan jemaat, maka transformasi kehidupan jemaat akan digagalkan. Penelitian ini menggunakan kaidah deskriptif dan fenomenologi analisis atas data-data yang dikumpulkan untuk menemukan jawapan mengapa kehidupan dan cara hidup banyak jemaat tidak berubah. Hasil analisis ini akan memberi dorongan kepada gereja untuk memperoleh teologi yang sehat untuk membangun gereja yang sehat yang hidup dalam Kristus Yesus.

Kata-kata kunci: Berkhotbah dan Mengajar, Pemimpin Gereja, Doktrin Sehat, Doktrin Kristosentrik, Transformasi

\section{INTRODUCTION}

The Borneo Evangelical Mission (BEM) began as a church in the rural area of Borneo Island, which started in a remote town of Lawas in the State of Sarawak, Malaysia in 1930, though BEM was first established in Limbang in 1928, through a three (3) member-team of missionaries from Australia. ${ }^{5}$ Those called for the ministry at the early stage of the formation of the church to help the Australian missionaries were uneducated and had only minimal primary education of maybe the highest education was standard four or Primary four, but with pure heart to serve the Lord. Though it has a short history of 91 years compared to the Anglican Church and Roman Catholic Church in Sarawak, the number of Christians and churches within the BEM Church have greatly increased. There has been a rapid growth, but many are also found to live like they are not Christians after having moved to the towns or cities to further their studies or obtained employment in the Government services or in the

\footnotetext{
${ }^{5}$ https://en.wikipedia.org/wiki/Borneo_Evangelical_Mission. Retrieved on 31.1.2019; Lees, Shirley. Drunk before dawn, OMF, 1979, Story of the Borneo Evangelical Mission; Tan Jin Huat. Planting an Indigenous Church : The case of the Borneo Evangelical Mission (Regnum Studies in Mission, 2011, Oxford: Regnum Books International; Perlembagaan Borneo Evangelical Mission (Sidang Injil Borneo), Pindaan 21 November 2018, Persidangan Agung Tahunan BEM-7, Miri
} 
private sectors. They appeared to have being influenced by the surrounding heresies and the many pseudo-religions.

That problem begins with the Christians' lives. The issue really started from preaching and teaching to Christians that had not changed their way of life and values. It is the biggest challenge. So, what has become of Malaysian Churches or even BEM Church in the 21st century, what is the problem or what? The modern BEM Church needs to tackle the problem properly.

A healthy theology is needed for the church to be revitalised and put back in its original form as a healthy church. Based on the above main problem, the researcher has decided to solve the problem through a comprehensive research with the title, "Preaching and Teaching Sound Doctrine based on Christocentric Doctrine by Church Leaders for the transformation of the Church Members of Borneo Evangelical Mission (BEM), Sarawak, Malaysia." [Berkhotbah dan Mengajar Pengajaran yang Sehat berdasarkan Doktrin Kristosentrik oleh Pemimpin Gereja Sebagai Sarana Transformasi Pola Hidup Jemaat Di Gereja Sidang Injil Borneo atau Borneo Evangelical Mission (BEM), Sarawak, Malaysia.]

In Christianity the task of preaching is of great importance. Through Christianity history it can be seen. Looking at it in detail, the preaching is the core of Christianity, and a fact that many people come to Jesus was found through that. In Acts 6:7 the importance of preaching is confirmed. New American Standard Version Bible says, "The word of God kept on spreading; and the number of the disciples continued to increase greatly in Jerusalem, and a great many of the priests were becoming obedient to the faith."

In his book, A History of Preaching, Edwin Dargan said, "Preaching is an essential part and a distinguishing feature of Christianity." ${ }^{6}$ And P. T. Forsyth discussed the importance of preaching in his book, "With preaching, Christianity stands or falls, because it is the declaration of the gospel."7

By this date, the preaching that laymen most wanted is based on prosperity theology and healing theology when examining the preaching and teaching of pastors as well as other Church leaders. In BEM Church, blessed or healing preaching was strong. Most sermons say that after believing in God and gaining salvation and devoting themselves to the Church, believers will receive blessing or healing. Believers would never expect spiritual development from preaching like this. The preaching is not the preaching which will assist

${ }^{6}$ Edwin Charles Dargan, A History of Preaching Volume 1 (Grand Rapids: Baker Book House, 1954), 12.

\footnotetext{
${ }^{7}$ P. T. Forsyth, Positive Preaching and the Modern Mind (Grand Rapids: Eerdmans, 1964), 5
} 
them. God only exists in the preaching to bless them or to cure them. If the blessing or healing is not received, then God is useless to them. God is useless to such believers though he exists. Then this scenario leads to the believers having no spiritual growth.

The church appears to be searching for other elements for the growth of church as approaches such as worship music \& concert, counselling, and special events, etc. Because of these reasons, the importance and role of preaching has diminished and other reasons have tended to replace preaching and thereby preaching has bored believers. So, they demand less of the preaching time. It is a preaching crisis and a pulpit and church crisis.

Therefore, to solve the above problem, the researcher of this study develops the following set of questions in a more detailed and structured manner :

1. What is the meaning of preaching and teaching? Any differences between them?

2. What is sound doctrine and Christocentric Doctrine? And how does it bring about transformation in the lives of Christians?

3. As preacher and teacher, what are the roles and responsibilities of Church leaders?

4. How to preach and teach sound doctrine based on Christocentric Doctrine for the transformation of Christians, especially in the church of Borneo Evangelical Mission (BEM)?

\section{METHODOLOGY}

The research methodology adopted is a descriptive and phenomenological qualitative study. According to Ethridge (2004), “descriptive studies may be characterised as simply the attempt to determine, describe or identify what is, while analytical research attempts to establish why it is that way or how it came to be." ${ }^{.8}$ Descriptive research is "aimed at casting light on current issues or problems through a process of data collection that enables them to describe the situation more completely than was possible without employing this method."

Descriptive studies are used in its nature to describe the various aspects of the phenomenon. It is utilized in its traditional format to define sample population characteristics and/or behaviour. On the other hand, phenomenology is a qualitative research method which is used to describe how a certain phenomenon is experienced by humans. A phenomenological study tries to set aside biases and preconceived assumptions about human experiences, feelings, and responses to a given situation. It helps the researcher to look into

\footnotetext{
${ }^{8}$ Ethridge, D.E. "Research Methodology in Applied Economics" John Wiley \& Sons, 2004, p.24

${ }^{9}$ Fox, W. \& Bayat, M.S. “A Guide to Managing Research” Juta Publications, 2007, p.45
} 
the experiences, viewpoints, understandings, and emotions of certain people who actually witnessed or observed the fascinating phenomenon or circumstance. ${ }^{10}$

The aim of this study is to ascertain the role of Christocentric sermons (preaching and teaching) in changing the life style and values of Christians. This research explored why many mostly new Christians do not change their way of life and values.

\section{DISCUSSION}

\section{Meaning of Preaching or Teaching}

Paul spoke of both of these acts and at the same time clearly found variations and similarities (1 Tim. 5:17). Preaching is the proclamatory act. The preacher preaches the Scriptures inside the church life. Taking from the basic words found in the Bible, preaching is meant to herald the reality or truth of the Word of God.

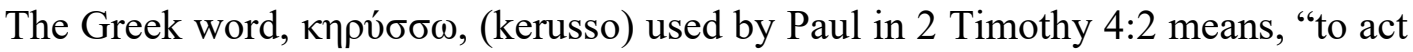
as a herald and make an official announcement, to proclaim aloud, to make public declarations."

The image here is one of the town heralds who would enter a village, draw everyone's attention by blowing a horn or signalling everyone to gather around, and then immediately after the people's hush, he would make a public announcement on behalf of the king and with the king's own authority. Haddon Robinson writes, "Ideally each sermon is the explanation, interpretation, or application of a single dominant idea supported by other ideas, all drawn from one passage or several passages of the Scriptures." ${ }^{11}$ Preachers make public declarations with the King of Kings' authority. That's what preaching is about-proclaiming the truth of the word of God. Preaching includes: proclamation, explanation, confrontation, exhortation, correction, persuasion, motivation, building up, illustration, application, and conclusion.

The act of preaching includes zeal, humility and a desire to simultaneously impart reality. By writing, Martyn Lloyd-Jones described preaching: What preaching is that? On Fire Logic! Preaching is theology which comes from a man on fire. To this must lead a true understanding of and experience of the Truth. Again, I say that a man who can speak

\footnotetext{
${ }^{10}$ Giorgi, A. The theory, practice, and evaluation of the phenomenological method as a qualitative research procedure. Journal of Phenomenological Psychology, 1997, 28(2), 235-260

${ }^{11}$ Haddon Robinson, Biblical Preaching, (Grand Rapids: Baker, 1980), 33.
} 
dispassionately about these things has no right whatsoever to be in a pulpit; and should never be allowed to enter one. ${ }^{12}$

While teaching is similar to preaching, there are differences to note. Teaching gives people the facts but the act and meaning will look and feel differently. The Greek word, $\delta 1 \delta \alpha ́ \sigma \kappa \omega$, (didasko) used in 2 Thessalonians 2:15, means, "to tell someone what to do, to instruct, to provide instruction in a formal setting." The teaching job is less heralding, and more oriented to discipleship. Teaching is essentially the classroom style of conveying knowledge and attempting to apply it while ensuring that the student understands the facts. There is always a lecturing dimension to the event when teachers are teaching the facts. Often there will be an element of discussion involved in teaching which provides immediate and on-the-spot feedback which is missing from the sermon context. Other external tools like laser pointers, media devices, audio or video clips, and various other tools are employed in the teaching setting to drive the truth home. Those elements are often missing in the event of preaching. John Piper does not allow preachers to use visual media when preaching in the pulpit, but suggests that such devices should be reserved for other teaching environments.

All pastors are to be teachers (Ephesians 4:11). Therefore there has to be teaching in every sermon. There is a healthy and natural overlap between preaching and teaching. Not all who teach will make a good preacher. Not everyone in the pulpit who is competent will make a good teacher.... But at some level there's always a natural, necessary overlap.

Paul and Barnabas were apparently engaged in both the ministry of "teaching and preaching" (Acts $5: 42 ; 15: 35$ ). The church has to have preaching as well as teaching. The people would be spiritually starving without preaching and teaching overlap and giftedness in the church. All preaching and teaching serve the church by equipping the saints for the work of ministry, leading the people to exult in God, revealing the glory of God which leads to doxology, and breaking the church's hearts for the unbelieving masses among the nations.

Preaching strengthens teaching, and teaching enhances preaching. The church that minimizes (or both) preaching or teaching will endure a long list of perils. In his book, Toward an Exegetical Theology, Walt Kaiser writes:

"It is no secret that Christ's Church is not at all in good health in many places of the world. She has been languishing because she has been fed, as the current line has it, "junk food"; all kinds of artificial preservatives and all sorts of unnatural substitutes have been served up to her. As a result, theological and Biblical malnutrition has afflicted the very

\footnotetext{
${ }^{12}$ Martyn Lloyd-Jones, Preaching and Preachers, (Grand Rapids: Zondervan, 1971), 97.
} 
generation that has taken such giant steps to make sure its physical health is not damaged by using foods or products that are carcinogenic or otherwise harmful to their physical bodies. Simultaneously a worldwide spiritual famine resulting from the absence of any genuine publication of the Word of God (Amos 8:11) continues to run wild and almost unabated in most quarters of the Church." 13

The need for the hour is to affirm faithful and passionate expository preaching through accurate and careful teaching that exalts God, convicts sinners and fuel healthy growth. God wants the church to expand by declaration and clarification-preaching and teaching the gospel (Matt. 28:18-20). Preachers shouldn't fear going deep and teachers shouldn't be afraid of passionate declaration. The truth of God is not reserved for the classroom of the seminary, therefore God wants preachers to teach. Paul commanded Timothy both to preach and to teach.

2 Timothy 4:1-2 - "I charge you in the presence of God and of Christ Jesus, who is to judge the living and the dead, and by his appearing and his kingdom: preach the word; be ready in season and out of season; reprove, rebuke, and exhort, with complete patience and teaching."

\section{Sound Doctrine : Christocentric Doctrine}

Strong theology or sound doctrine is of utmost importance in preaching and teaching the word of God. Doctrine is not just a teaching, it is a particular teaching on absolute truth. When the Bible speaks of sound doctrine, it speaks of absolute reality as set out in his word by God : Matt. 7:28, 15:9; Isa. 28:9; Deut. 32:2. In 2 Timothy 4:3-4 (KJV), This verse says: For the time will come when they will not endure sound doctrine; but after their own lusts shall they heap to themselves teachers, having itching ears; And they shall turn away their ears from the truth, and shall be turned unto fables. Henceforth, Paul charges Titus (Titus 2:1 (ESV)) : "But as for you, teach what accords with sound doctrine." A mandate like that makes it obvious that sound doctrine is essential. And it has to be Christocentric doctrine.

Christocentric is a doctrinal concept within Christianity that defines the theological roles that concentrate on Jesus Christ, the second individual of the Christian Trinity, in relation to the Godhead / God the Father (theocentric) or the Holy Spirit (pneumacentric). Christocentric theologies make Christ the central subject of all other theological positions /

${ }^{13}$ Walter C. Kaiser, Jr., Toward An Exegetical Theology (Grand Rapids: Baker Book House, 1981), 
doctrines. It is necessary to teach the doctrines of the Father, Son and Holy Spirit with equal emphasis so that Christians will know what they believe.

There are far too many churches today, for example, that are Pneumacentric, having been influenced by hyper-Pentecostalism and Latter Rain. They spend most of their time focusing on the Holy Spirit to the exclusion of preaching the Gospel while, in fact, they don't even have a biblical doctrine of the Holy Spirit. This happened because to some degree classic evangelicals dropped the ball in identifying the person and function of the Holy Spirit that it gave Third Wavers an opportunity to step in with their misguided ideas of pnematology.

But should biblical churches be Christocentric? Yet not to the exclusion of a good understanding of the other main doctrines of faith... Yes! Yeah! Why? For that is the emphasis given to Christianity by the New Testament, the Father, the Son, the Holy Spirit and the Apostles. So we should do no less.

\section{The New Testament is Christocentric.}

In the New Testament the words "Christ" and "Son" are repeated 720 times, while the word "Father" is used only 297 times and the word "Spirit" is used only 274 times. The New Testament 's emphasis is clearly Christocentric.

\section{The Father wants us to be Christocentric}

Matthew 17:5 While he was still speaking, a bright cloud enveloped them, and a voice from the cloud said, "This is my Son, whom I love; with him I am well pleased. Listen to him!"

Phil. 2:9-11 Therefore God exalted him to the highest place and gave him the name that is above every name, that at the name of Jesus every knee should bow, in heaven and on earth and under the earth, and every tongue confess that Jesus Christ is Lord, to the glory of God the Father.

\section{The Son wants us to be Christocentric.}

John 14:6 Jesus answered, "I am the way and the truth and the life. No one comes to the Father except through me.

John 11:25-26 Jesus said to her, "I am the resurrection and the life. He who believes in me will live, even though he dies; and whoever lives and believes in me will never die. Do you believe this?" 


\section{The Holy Spirit is Christocentric.}

John 15:26-27 "When the Counselor comes, whom I will send to you from the Father, the Spirit of truth who goes out from the Father, he will testify about me. And you also must testify, for you have been with me from the beginning.

John 16:13-15 But when he, the Spirit of truth, comes, he will guide you into all truth. He will not speak on his own; he will speak only what he hears, and he will tell you what is yet to come. He will bring glory to me by taking from what is mine and making it known to you. All that belongs to the Father is mine. That is why I said the Spirit will take from what is mine and make it known to you.

\section{Paul was Christocentric.}

1 Corinthians 2:2 For I resolved to know nothing while I was with you except Jesus Christ and him crucified.

Galatians 6:14 May I never boast except in the cross of our Lord Jesus Christ, through which the world has been crucified to me, and I to the world.

\section{Peter was Christocentric.}

1 Peter 4:11 If anyone speaks, he should do it as one speaking the very words of God. If anyone serves, he should do it with the strength God provides, so that in all things God may be praised through Jesus Christ. To him be the glory and the power for ever and ever. Amen.

\section{Luke was Christocentric.}

Acts 4:12 Salvation is found in no one else, for there is no other name under heaven given to men by which we must be saved."

\section{The author of Hebrews was Christocentric.}

Hebrews 12:2 Let us fix our eyes on Jesus, the author and perfecter of our faith, who for the joy set before him endured the cross, scorning its shame, and sat down at the right hand of the throne of God.

\section{Summary - Christocentric}

The truth is that true Christian biblical faith is Christocentric, since this is the importance that the Holy Trinity and the Apostles have provided. We should teach about the Father and the Holy Spirit, and have a correct understanding of Who they are. But the true Church has always had the central focus on Jesus Christ. Any church that takes its emphasis off Christ's central theme is on the path to apostasy. Without the Son, you can not have either 
the Father or the Holy Spirit. The Son is the "centre" of the whole of history and eternity. Let us preach and teach the Son, so that all can know the Father, the Son and the Holy Spirit!

It is important to have sound doctrine based on Christocentric doctrine because our faith is based on a specific message. The Church 's overall teaching contains many elements but the primary message is explicitly defined: Christ died for our sins according to the Scriptures [and] ... he was raised on the third day according to the Scriptures" (1 Corinthians $15: 3-4)$.

This is the unambiguous good news, and it is "of prime importance." Change that message, and the foundation of faith shifts from Christ to something else. Our eternal fate depends on hearing "the word of truth, the gospel of your salvation" (Eph. 1:13; see also 2 Thess. 2:13-14).

The superiority of doctrine can be seen in (2 Tim. 3:16) "All scripture is given by inspiration of God, and is profitable for doctrine, for reproof, for correction, for instruction in righteousness..."

\section{Christocentric Doctrine as the Source of Life}

By faith in Christ the doctrine of redemption imparts everlasting life by grace. God spoke at the beginning and creation began immediately, and so it is with the second birth. When a person repents of his sin and acknowledges Jesus Christ as Lord and Savior, the Spirit who raised Christ from the dead instantly dwells in him and fasters or quikens the spirit of the new believer. This triggers a crucial inner transition, two spirits become one (1 Corinthians 6:17); a divine transformation takes place from spiritual death to spiritual life.

Before salvation, the devil used the false doctrines of religion, philosophy, evolution, etc. to deceive us, to keep us blind to the truth of God. The second birth is a prime example of how life is based on the sound doctrine of the living word of God.

Spiritual life started when we believed the word of God (the sound doctrine of): "The Lord Jesus Christ's Gospel." "That if thou shalt confess with thy mouth the Lord Jesus, and shalt believe in thine heart that God hath raised him from the dead, thou shalt be saved" (Rom. 10:9). "Being born again, not of corruptible seed, but of incorruptible, by the word of God, which liveth and abideth for ever" (1 Peter 1:23).

There are a multitude of different religious teachings (doctrines) about man's redemption, but only one is valid! "Neither is there salvation in any other: for there is none other name under heaven given among men, whereby we must be saved" (Acts 4:12). Jesus 
proclaimed "...I am the way, the truth, and the life: no man cometh unto the Father, but by me" (John 14:6).

\section{Sound Doctrine based on Christocentric as the truth that transform the life}

"Therefore if any man be in Christ, he is a new creature: old things are passed away; behold all things are become new" (2 Cor 5:17).

Born again, it's all about spiritual change: "new creation," "new guy," "fresh soul," "new spirit." It's not about having religion or converting to another faith, turning a new leaf over, or vowing to be a better person: new life starts where there was none before.

The wonderful miracle of the second birth, however, is only the beginning of CHANGE; the starting point for an entire new life, “...he which hath begun a good work in you will perform it until the day of Jesus Christ" (Phil. 1:6).

The purpose of the death, burial and resurrection of Jesus is concerned not only with the salvation of the soul but with the transformation of life. "To reveal his Son in me..." (Gal.1:16). Not only does the cross secure eternal life but it also allows the transformation of present life: "to be conformed to the image of his Son." (Rom.8:29). The aim is to build "Christ-like character"... a complete shift of HEART, OUTLOOK and PRIORITIES “...by the renewing of your mind" (Rom.12:2). "The entrance of thy words giveth light..." (Ps. 119:130).

This involves a yielding process by which we allow the truth of God's word to reshape our thinking, restructure our priorities, and recentralize our outlook... so that our way of thinking, living, and responding is in line with His. But there are many believers who seem unaware of this basic truth and fail to grasp thoroughly the meaning of salvation. This condition had led Apostle Paul to split the Corinthian Christians into two categories: the spiritual and the fleshly or carnal; consider: "And I, brethren, could not speak unto you as spiritual, but as unto carnal, even as babes in Christ. I have fed you with milk, and not with meat: for hitherto ye were not able to bear it, neither yet now are ye able. For ye are yet carnal: for whereas there is among you envying, and strife, and divisions, are ye not carnal, and walk as men?" (1 Cor 3:1-3).

The verses above specifically represent two groups of believers; those who are spiritual, and those who are carnal. Those who assimilate and apply the word of God (sound doctrine), and those who don't.

There are christians who have grown up in God's grace and understanding and recognize the meaning of being "in Jesus" unlike others who sadly remain babes in the Lord. 
Growth is the contrast between discord and harmony...... sterile Christians and Christians who bear fruit.

For young believers it's very common to be carnal or fleshly. Spiritual maturity does not occur immediately, it calls for time and opportunity. By faith, the child must learn to resist the flesh and submit to a cycle of redemption, realizing first-hand through a battle with sin and self that "flesh profiteth nothing" (John 6:63).

This present crisis within Christianity will not come as a surprise: "Now the Spirit speaks clearly, that in the latter times some shall depart from faith, giving heed to seducing spirits, and the doctrines of devils..." (1 Tim.4:1).

Paul made it very clear in the book of 2 Thessalonians that the coming of Christ will not occur until those conditions are fulfilled: “...a falling away first, and that man of sin be revealed, the son of perdition" (2 Thess.2:3). A falling apart or mass apostasy, along with the revealing of the Antichrist, precedes the "Day of Christ."

"For the time will come when they will not endure sound doctrine..." (2 Tim. 4:3). Indeed, what has been prophesied about the collapse of sound doctrine has come to pass in our day and is responsible for the present spiritual crisis in many respects.

The crucial requirement of the hour is for leaders like Issachar 's men, "men that had understanding of the times, to know what Israel ought to do..." (1Chron. 12:32). The need to teach the people of God extensively about the life-changing teachings of the Scriptures is greater now than ever before. Paul reminds Timothy, "Take heed unto thyself, and unto the doctrine; continue in them: for in doing this thou shalt both save thyself and them that hear thee" (1 Tim. 4:16).

"Heaven and earth shall pass away, but my Words (sound doctrine) shall not pass away." (Matt.24:35 K.J.B). He assigned the Church (pastors, teachers, and elders) with that responsibility: " Let the elders that rule well be counted worthy of double honour, especially they who labour in the word and doctrine." (1 Tim.5:17).

The Bible teachings are, "For the perfecting of the saints, for the work of the ministry, for the edifying of the body of Christ" (Eph. 4:12). Note, perfecting the saints is a prerequisite for the ministry 's work. "... be ready always to give an answer to every man that asketh" (1Peter 3:15) and first they need to be grounded in sound doctrine.

"That we henceforth be no more children, tossed to and fro, and carried about with every wind of doctrine, by the sleight of men, and cunning craftiness, whereby they lie in to deceive". (Eph. 4:14) 


\section{Christocentric Preaching and Teaching}

Christocentric preaching and teaching transforms a new individual. Change in form, condition, character or substance is being transformed. The Gospel of Romans in chapter 12:1-2 has given a good explanation of such a transition : "I appeal to you therefore, brothers, by the mercies of God, to present your bodies as a living sacrifice, holy and acceptable to God, which is your spiritual worship. Do not be conformed to this world, but be transformed by the renewal of your mind, that by testing you may discern what is the will of God, what is good and acceptable and perfect." (Romans 12:1-2).

The new man, is also full of God's righteousness and holiness. In Ephesians 4:24, Paul wrote; "and put on the new self, which is in the likeness of God." In the righteousness and holiness of truth the new man was created. This new man is also to be renewed in the image of God (Colossians 3:10).

After meeting Christ, man's spirit is transformed into a man dedicated to Christ, and he begins to develop a mature faith and style of Christian life. The new man is becoming more and more like Jesus Christ.

In 2 Cor. 3:18, having contrasted the Christian's higher life of the Spirit with the life of the old covenant of the letter of the law, Paul sums it up in this way: "And we ... are being transformed into his likeness with ever-increasing glory, which comes from the Lord, who is the Spirit." The purpose of transforming the new believers is to be like Jesus ${ }^{14}$

In the Bible, of course, the transformation means changing or renewing from an old man's life. It no longer conforms to the world's ways which are not acceptable to God (Romans 12:2). This, too, is achieved by the regeneration of the mind of the believer through an inner spiritual transformation which will manifest in outward acts. In Christ the transformed life is"bearing fruit in every good work, growing in the knowledge of God" (Colossians 1:10). Transformation therefore implies that believers in Christ Jesus who once were far away were brought close to the blood of Christ (Ephesians 2:13), increasingly reflect the likeness and glory of Christ (2 Corinthians 3:18), controlled not by sinful nature but by the Spirit (Romans 8:9) and living by faith in the Son of God (Galatians 2:20);

${ }^{14}$ William D. Mounce, Complete Expository Dictionary of Old \& New Testament Words (Zondervan: Grand Rapids, Michigan, 2006), 739. 


\section{Responsibilities of Church Leaders : Method to preach a Christocentric Doctrinal Preaching and teaching}

In the results of the study, the pastors or preachers generally chose preaching and teaching as the highest rate $(71.4 \%)$ in the need for church members to grow spiritually or for a need for a transformed christian, besides other elements of church growth like discipleship (14.2\%), relationship in small group (7.2\%), attending conference (7.2\%), etc. The laymen or non-preachers generally also agreed that preaching and teaching the Word of God is a very important factor for their spiritual growth (48.8\%).

The study also shows that in preparation of a sermon, majority of pastors or preachers reported between 5-10 hours (35.7\%) and less than 5 hours (14.3\%). Exegesis (7.1\%), crossrefernce to commentaries $(50 \%)$ and referring to books $(57.1 \%)$ are not fully done. The preaching style preferred is topical sermon $(28.6 \%)$, but chose "strongly or more" for question on "Do you think moral view or life-style can be changed by doctrinal preaching?" $(64.3 \%)$ when doctrine sermon carries $7.1 \%$ only. They also chose strong or over as positive answer to question on "the doctrinal preaching can deliver God's grace to listeners" (50\%); "doctrinal preaching can show an awareness of contemporary issues" (50\%); and "doctrinal preaching can provide practical examples or advice for your life" (71.4\%). However, here, it shows that they actually preferred topical sermons compared to doctrinal sermons.

It is reiterated hereby that to be understood, a Christocentric doctrinal sermon has to be clearly defined. The reason a Christ-centered sermon is required is because the New Testament sermons were centered around Christ. Sidney Greidanus says the New Testament sermons can be known as being truly centered on Christ. This is not just a narrow-sense sermon focusing on the death of Christ on the cross, but in the broad sense centering on the second person in the Trinity or the eternal Logos. The Church of the New Testament proclaimed the birth, ministry, death, resurrection and ascension of Jesus of Nazareth as the fulfillment of the prophecies and promises of God, and proclaims the presence of Christ on today and the approach of the Second Coming of Jesus. Simply saying, New Testament preaching about Christ means spreading Christ out of the context as the whole area of redemption. $^{15}$

He also states that preaching Christ who died on the cross would connote greater and greater significance than that all sermons would make the cross of Christ misery the focus of preaching. As clearly seen by the sermons and letters of Paul, the cross of Christ reveals

15 Sidney Greidanus, tr Jin Sub Kim, Ho Young Reu, \& Ho Jun Reu, Preaching Christ from the Old Testament (Grand Rapids: Wm. B. Eerdmans, 1999), 32, 33 
much more than the sufferings of Jesus alone and gives an insight to the perfect justice of God and the calamity of the sin of man. ${ }^{16}$ Both many old men and new men witnessed a change in the New Testament churches through Christ-centered sermons, and became mature Christians. This fact proves the need for Christ-centered sermons for the current generation too. Therefore it includes Christ-centered sermon. Preaching about Christ is that Christians must believe, trust, love and obey Him, and it includes Christ 's personality and ministry and various aspects of His teachings. The meaning of preaching Christ mentioned by Sidney Greidanus is the preaching that genuinely unifies the text message with the peak of God's revelation in the person, ministry, and/or teaching of Christ Jesus as revealed in the New Testament. ${ }^{17}$

In order to preach a sermon centered on Christ, pastors are also required to preach a sermon centered on God. Christ is the core theme of the Old Testament and the Old Testament shows that Christ fulfilled the mission of God. Sydney Greidanus claims that one can not separate Christ and God. ${ }^{18}$ That is why God sent Christ into this world, and Christ fulfilled the work of God, and sought the glory of God. Paul also teaches that one can not separate God and Christ from the Corinthians 1 and 2. He 's telling, "but we preach Christ crucified: a stumbling block to Jews and foolishness to Gentiles," (1 Corinthians 1:23 NIV) and states too, "For what we preach is not ourselves, but Jesus Christ as Lord, and ourselves as your servants for Jesus' sake. For God, who said, "Let light shine out of darkness," made his light shine in our hearts to give us the light of the knowledge of God's glory displayed in the face of Christ"'(2 Corinthians 4:5-6 NIV).

Paul states in Romans 10:14-15, that a sermon based on God is a sermon centered on Christ: "How, then, can they call on the one they have not believed in? And how can they believe in the one of whom they have not heard? And how can they hear without someone preaching to them? And how can anyone preach unless they are sent? As it is written: "How beautiful are the feet of those who bring good news!"(Romans 10:14-15 NIV).

The author of the John Gospel also provides evidence that, before the birth of Christ in this world, He was with God and accomplished His work with God. Paul also promotes the Gospel in his sermons and letters, and the author of Luke states that after the resurrection of Christ, Jesus interpreted and explained the Old Testament prophecies of the prophets to the disciples who were going to Emmaus. So it is not wrong to say that preaching Christ is

\footnotetext{
16 Ibid.

${ }^{17}$ Ibid, 41

18 Ibid.
} 
preaching about the nature and work of God. Therefore all of a preacher's sermons must become sermons centered on God and centered on Christ.

To preach a doctrinal sermon centered on Christ, a brief explanation about biblical theology must be given. Geerhardus Vos described a theology of the Bible as, "the department handling the procession of God's revelation deposited in the Bible." $19 \mathrm{He}$ claimed that the revelation of God was full in history, and included historical progressivity. A biblical theology, therefore, refers to the theology which takes up the Bible itself and provides understanding from the biblical point of view. It describes how it was then that the revelation of God was understood. Not only does a preacher need a correct biblical theology for a proper sermon, but he also needs to have complete knowledge of systemic theology, because biblical theology focuses on revelations of the textual circumstances of the entire Bible, while systematic theology can concentrate on the circumstances that can be applied to life according to the Christian doctrine found in the text.

Preachers therefore need theology to prepare doctrinal Christocentric preaching and pastors should be trained in systematic theology and biblical theology. Biblical theology describes the Bible's historical, literary, and grammatical circumstances and systematic theology safeguards congregations from heresies. Biblical theology arranges Christian doctrines in an orderly manner, reveals doctrines that God wants to convey, leads congregations to live in the world righteously, and teaches them the Biblical values and ways of living in the world. The texts chosen for Christocentric doctrinal preaching should therefore be interpreted on a firm basis of biblical theology and systematic theology, and pastors should seek to discover the theological subject and the theme for Christocentric doctrinal preaching in the given text.

The preachers should interpret and explain the text for the Christocentric doctrinal preaching. They will deliver their own thoughts, or make assertions without the text, unless they take this process. For Christocentric doctrinal preaching, then, preachers should follow this process: The intention of the author (including the historical and literary situation), the exegesis (translation of Greek or Hebrew texts, historical context, searching for a hidden message and theological doctrinal factor $)^{20}$ and typology (typology may find exposed in the Old Testament the design and providence of God for the Israelites and Christ and the

${ }^{19}$ Geerhardus Vos, Biblical Theology: Old and New Testaments (Grand Rapids: Eerdmans, 1948), 13. Graham Goldworth, How to do a Biblical theological sermon, chapter3, 53.

${ }^{20}$ Douglas Stuart, Old Testament Exegesis: A Handbook for Students and Pastors Fourth edition (Louisville, Kentucky: WJK, 2009). 
redemption of God; able to reveal the intention of the author, the revelation of God, and the doctrines covered by the text). ${ }^{21}$ The final stage is illustration and application (use a real-life illustration, make sure the illustration does not distort or misconceive the Biblical truth). Bryan Chapell spoke of the reason why it is necessary: "Illustrations do not allow mere intellectual knowledge. By grounding biblical truths in situations that people recognize, illustrations unite biblical truth with experience and, in so doing, make the Word more accessible, understandable, and real in ways that propositional statements alone cannot"22 An illustration thought Word of the Bible should also be applied.

A sermon's goal is to bring about holy transformation in listener's life through God's word. The preachers are expected to help the audience apply the Word in their lives. In this way, Bryan Chapell notes that "without application, a preacher has no reason to preach." 23 Therefore the following five questions for the application should first be applied to the preachers themselves for Christocentric doctrinal preaching. Through these questions, preachers can help change the life of the congregation through the application of doctrinal Christocentric preaching. The following five questions are: What is going to be applied?, Whom it must be applied to?, Why the application must occur?, How it must be applied?, Where it is applied? The importance of the application, according to David Veerman, is that people understand how to use what they have been taught, and what they can do through applications. Applications are causing the action they should be taking. ${ }^{24}$

\section{CONCLUSION}

Based on the analisis done, for Christocentric doctrinal preaching to be effectively carried out in the BEM Church, the results of the study concluded that the following factors, inter alia, need to be observed and practised by the church in general. Fistly, the management, through the President of BEM Sarawak as well as the District Superintendent of BEM churches in various Districts and its line management must demonstrate their commitment such that they affect all levels of expression in the development of the Church as a whole to revitalise the church with sound doctrine based on Christocentric preaching and teaching for a healthy church. As a show of commitment, the management of BEM

${ }^{21}$ Lee Kwang Joo, University and Mission: Typological Preaching for Christ-Centered Sermon (Seoul: Korea University Mission Association, 2003) 252-285.

${ }^{22}$ Bryan Chapell, Christ-Centered Preaching, 178

${ }^{23}$ Bryan Chapell, Christ-Centered Preaching, 210

${ }^{24}$ Veerman David, Sermon: Apply Within Leadership (Spring 1990), 122. Bryan

Chapell also quoted his speaking in his book, Christ-Centered Preaching, 210. 
Sarawak must provide adequate resources including proper guidelines for Pastors or Preachers on sermon preparation at its various ministries. Not only does a preacher need a valid biblical theology for a good sermon, but he also needs to have thorough knowledge of systematic theology, since biblical theology focuses on discoveries of the textual circumstances of the whole Bible, while systematic theology will concentrate on the circumstances that can be applied to life according to the Christian doctrine contained in the text.

Secondly, to establish and develop a more practical method to preach a Christocentric Doctrinal Preaching as laid down in my above discussion on "Responsibilities of Church Leaders : Method to preach Christocentric doctrinal preaching and teaching." Briefly, the preachers should interpret and explain the text for the Christocentric doctrinal preaching. They will deliver their own thoughts, or make assertions without the text, unless they take this process. For Christocentric doctrinal preaching, therefore, preachers should follow this process: the intention of the author, the exegesis and the typology. The final stage is illustration and application. An illustration thought from Word of the Bible should also be applied.

\section{REFERENCES}

New American Standard Bible : The Holy Bible. 1995.

New International Version (NIV) : The Holy Bible. Zondervan, 1984

Chapell, Bryan. Christ-Centered Preaching: Redeeming the Expository Sermon. Grand Rapids: Baker Academic, 2005.

Dargan, Edwin Charles. A History of Preaching Volume 1. Grand Rapids: Baker Book House, 1954.

Ethridge, D.E. Research Methodology in Applied Economics. John Wiley \& Sons, 2004.

Forsyth, P. T. Positive Preaching and the Modern Mind. Grand Rapids: Eerdmans, 1964.

Fox, W. \& Bayat, M.S. A Guide to Managing Research. Juta Publications, 2007.

Vos, Geerhardus. Biblical Theology: Old and New Testaments. Grand Rapids: Eerdmans, 1948.

Giorgi, A. "The theory, practice, and evaluation of the phenomenological method as a qualitative research procedure," Journal of Phenomenological Psychology, 1997, 28(2), 235-260

Graham Goldworth. How to do a Biblical Theological Sermon.

Greidanus, Sidney tr Jin Sub Kim, Ho Young Reu, \& Ho Jun Reu. Preaching Christ from the Old Testament. Grand Rapids: Wm. B. Eerdmans, 1999.

Haddon W. Robinson. Biblical Preaching: The Art and Craft of Biblical Preaching.

Kaiser, Walter C. Jr,. Toward an Exegetical Theology: Biblical Exegesis for Preaching and Teaching. Grand Rapids: Baker Academic, 1998.

Lloyd-Jones D Martyn. Preaching and Preachers. Grand Rapid: Zondervan, 1971.

Lee Kwang Joo. University and Mission: Typological Preaching for Christ-Centered Sermon. Seoul: Korea University Mission Association, 2003. 
Lees, Shirley. Drunk before dawn: Story of the Borneo Evangelical Mission. OMF, 1979, Mounce, William D. Complete Expository Dictionary of Old \& New Testament Words. Grand Rapids: Zondervan, 2006.

Piper, John. The Supremacy of God in Preaching. Grand Rapid: Baker Book House, 2004. Rousseau, D. Assessing Organizatuional Culture : the case of multiple methods, in B. Schneider (ed), Organizational Climate \& Culture, San-Francisco : Jossey-Bass, 1990.

Stuart, Douglas. Old Testament Exegesis: A Handbook for Students and Pastors Fourth edition. Louisville, Kentucky: WJK, 2009.

Tan Jin Huat. Planting an Indigenous Church: The case of the Borneo Evangelical Mission. Regnum Studies in Mission, Oxford: Regnum Books, 2011

Veerman David. Sermon: Apply Within Leadership. Spring 1990. 